INSTITUT FRANÇAIS DU PÉTROLE (IFP)

ÉCOLE DU PÉTROLE ET DES MOTEURS (IFP School)

Centre Économie et Gestion

228-232 avenue Napoléon Bonaparte

92852 RUEIL-MALMAISON CEDEX

\title{
Investment project valuation: A new equity perspective
}

\author{
Denis BABUSIAUX \\ Axel PIERRU
}

February 2009

Les cahiers de l'économie - $n^{\circ} 70$

Série Recherche

denis.babusiaux@numericable.fr

axel.pierru@ifp.fr

La collection "Les cahiers de l'économie" a pour objectif de présenter des travaux réalisés à l'IFP et à l'IFP School, travaux de recherche ou notes de synthèse en économie, finance et gestion. La forme peut être encore provisoire, afin de susciter des échanges de points de vue sur les sujets abordés.

Les opinions émises dans les textes publiés dans cette collection doivent être considérées comme propres à leurs auteurs et ne reflètent pas nécessairement le point de vue de l'IFP ou de l'IFP School.

Pour toute information sur le contenu, prière de contacter directement l'auteur ;

Pour toute information complémentaire, prière de contacter le Centre Économie et Gestion: Tél. 0147527227 


\begin{abstract}
We suggest a new approach to calculating a project's net present value, termed the "displaced equity method". Based on a straightforward formula, it analyzes a project partially financed with debt from the perspective that every year the amount of outstanding debt displaces an equivalent amount of equity that otherwise would be tied up in the project. Although they represent distinct shareholders' perspectives, the displaced equity method and the equity residual method lead to the same investment decision. Every year, the project's value calculated with the displaced equity method is equal to the sum of the project's debt and equity values. In practice, when the schedule of expected outstanding debt amounts is known, using the displaced equity method is an easy way to estimate the project's net present value.
\end{abstract}




\section{INTRODUCTION}

To value a project, the key issue is to know if the firm undertaking this project targets a constant debt-to-value ratio. If such is the case, the project's value is obtained by discounting the project's operating cash flows at the firm's constant WACC discount rate (computed with the firm's target debt ratio). To determine the project's equity value by using the equity residual method, one must then consider a (theoretical) debt repayment schedule such that every year the project's debt ratio is equal to the firm's target debt ratio. In practice, the equity residual method is used when a predetermined stream of debt cash flows can be associated ${ }^{1}$ with the project under study. The project's equity value can then be calculated by considering this stream of debt cash flows. In this short note, we stick to the operational viewpoint usually adopted by industrial practitioners who define the project's cost of equity as being the minimum return-on-equity value required by the firm to undertake the project (under the assumptions made about financing). In other words, we consider that the project's cost of equity remains unchanged ${ }^{2}$ over the project's lifetime.

In this context, we suggest a new equity perspective that leads to a novel and straightforward valuation formula that does not require equity residual cash flows to be computed. Every year, it values an investment project partially financed with debt as the sum of its debt and equity values. This perspective is therefore that of shareholders considering the full project's economic value, whereas, in the usual equity residual method, shareholders only consider their invested equity. To determine the project's economic value has a practical interest: it represents the minimum cash amount at which the firm is willing to sell its stake in the project at any given point in time.

The paper is structured as follows. In the next section, notations are adopted and the usual equity perspective - i.e., the equity residual method - is briefly recalled. Next, the new equity perspective -i.e., the displaced equity method - is introduced. We prove that the usual and new equity perspectives are consistent. The practical interest of the displaced equity method is emphasized in the last section.

\footnotetext{
${ }^{1}$ This may happen in various instances: the project is the sole project of the firm (at least in a given class of risk), or it is financed by project finance, or the firm's stake in the project is consolidated by using the equity method (as defined in IAS 28), i.e. no debt associated with the project appears in the firm's consolidated balance sheet.

${ }^{2}$ The financial literature suggests formulas that yield a project's cost of equity susceptible to change over time when dollar amounts of outstanding debt are targeted; for instance, Inselbag and Kaufold (1997) derive a formula consistent with the adjusted-present-value approach, Ruback (2002) produces a formula consistent with the CAPM approach. When a fixed debt ratio is targeted, the cost of equity remains constant (see for instance Miles and Ezzell (1985), Harris and Pringle (1985) and Taggart (1991)). We further discuss this point in the last section.
} 


\section{THE USUAL EQUITY PERSPECTIVE: THE EQUITY RESIDUAL METHOD}

Let us consider a project generating every year $t$ the after-tax operating cash flow $f_{t}$. The project's lifetime extends from year 0 to $T$ (i.e., $f_{t}=0$ when $t>T$ ). The project is partially financed with debt. $D_{t}$ denotes the amount of outstanding debt associated with the project at the end of year $t$ (with $D_{t}=0$ when $t \geq T$, and $D_{-1}=0$ ). This debt is contracted at the annual interest rate $k_{d}$. The interest payments are assumed to generate tax shields at the corporate tax rate $\tau$. The cost of equity is denoted as $k_{e}$.

As recalled by Chambers et al. (1982), the equity residual method - also called flow-to-equity method - values the project (or the firm) under study from the invested-equity perspective. The cash flows considered are those available for distribution to the shareholders (i.e., each year, the after-tax operating cash flow minus the principal repayment and the after-tax interest payment). Each year $t$, the market value of equity $E_{t}$ is the sum of the present values of subsequent equity residual cash flows:

$$
E_{t}=\sum_{s=t+1}^{T} \frac{f_{s}+D_{s}-\left(1+(1-\tau) k_{d}\right) D_{s-1}}{\left(1+k_{e}\right)^{s-t}}
$$

(1) is equivalent to:

$$
E_{t-1}=\frac{E_{t}+D_{t}-\left(1+(1-\tau) k_{d}\right) D_{t-1}+f_{t}}{1+k_{e}}
$$

with $E_{T}=0$.

\section{THE NEW EQUITY PERSPECTIVE: THE DISPLACED EQUITY METHOD}

We now adopt the point of view of shareholders who consider the full project's value, and not their invested equity only. In this perspective, the debt amount associated with the project every year is considered as just replacing an equivalent amount of equity which, otherwise, would be tied-up in the project. The reinvestment of this displaced equity by the shareholders yields a return equal to their cost of equity ${ }^{4} k_{e}$.

In other words, in any year $t-1$, the oustanding amount of debt $D_{t-1}$ is merely viewed as a means of "freeing" an equivalent amount of equity that is immediately invested by the shareholders for one year at the return $k_{e}$. The cash flow yielded by this investment in the following year is $\left(1+k_{e}\right) D_{t-1}$. The actual gain for the shareholders in year $t$ is given by the

\footnotetext{
${ }^{3}$ Here, this term refers to the cash flow of the project before any financial claims are paid; for tax purposes, the taxable income used is defined as the earnings before interest and taxes, which means that the after-tax operating cash flow includes no interest tax shields; some authors also use the term "free cash flow".

${ }^{4}$ The cost of equity is here viewed as an opportunity cost, as the displaced amount of equity is implicitly assumed to be invested in other assets with a similar risk for the shareholders; this equity displacement remains a mere perspective, in the sense that the cost-of-equity value considered here is that corresponding to the financial structure of the project under study.
} 
difference between this cash flow and the sum of the after-tax interest payment and debt repayment:

$$
\left(1+k_{e}\right) D_{t-1}-\left(1+(1-\tau) k_{d}\right) D_{t-1}=\left(k_{e}-(1-\tau) k_{d}\right) D_{t-1}
$$

Therefore, in the displaced equity method, the shareholders' cash flow in year $t$ is:

$$
f_{t}+\left(k_{e}-(1-\tau) k_{d}\right) D_{t-1}
$$

The project's value $V_{t}$ in year $t$ is consequenty:

Or, equivalently:

$$
V_{t}=\sum_{s=t+1}^{T} \frac{f_{s}+\left(k_{e}-(1-\tau) k_{d}\right) D_{s-1}}{\left(1+k_{e}\right)^{s-t}}
$$

$$
V_{t-1}=\frac{f_{t}+V_{t}+\left(k_{e}-(1-\tau) k_{d}\right) D_{t-1}}{1+k_{e}}
$$

In particular, in year 0 , by using the notation $D_{-1}=0$, the project's net present value computed with the displaced equity method is:

$$
\sum_{s=0}^{T} \frac{f_{s}+\left(k_{e}-(1-\tau) k_{d}\right) D_{s-1}}{\left(1+k_{e}\right)^{s}}
$$

\section{CONSISTENCY OF THE TWO EQUITY PERSPECTIVES}

The following propositions are verified:

(i) each year $t$, the project's value obtained with the displaced equity method is equal to the sum of the project's debt and equity values:

$$
V_{t}=D_{t}+E_{t} \quad(\forall t)
$$

(ii) the equity residual method and the displaced equity method yield the same net present value and internal rate of return ${ }^{5}$.

Both equity perspectives are therefore consistent, since they lead to the same investment decision, as stated by (ii). However, as shown by (i), the displaced equity method leads to compute the "total" project's value (and not only the equity value).

Proof of (i) and (ii)

(i) is proved by recurrence:

In year T, (4) obviously holds since we have:

$$
V_{T}=E_{T}+D_{T}=0
$$

Let us now assume that (4) holds in year $t$ : $V_{t}=E_{t}+D_{t}$. By subtracting (2) from (3) we obtain:

\footnotetext{
${ }^{5}$ Note that the internal rate of return $r$ yielded by the displaced equity method is given by the following formula:

$$
\sum_{s=0}^{T} \frac{f_{s}+\left(r-(1-\tau) k_{d}\right) D_{s-1}}{(1+r)^{s}}=0
$$
}




$$
V_{t-1}-E_{t-1}=\frac{V_{t}-E_{t}-D_{t}+\left(1+k_{e}\right) D_{t-1}}{1+k_{e}}
$$

Since we assume that $V_{t}-E_{t}-D_{t}=0$, (5) gives:

$$
V_{t-1}-E_{t-1}=D_{t-1}
$$

The recurrence is over: (4) holds in any year $t$.

In year $0,(4)$ gives:

$$
V_{0}+f_{0}=E_{0}+D_{0}+f_{0}
$$

The left-hand side of (6) is the net present value computed with the displaced equity perpsective and the right-hand side of (6) is the net present value obtained with the equity residual method. Both net present values are therefore equal.

Since both equity perspectives use the same cost-of-equity discount rate and yield the same net present value, they necessarily yield the same internal rate of return. (ii) is therefore proved.

\section{PraCTICAL INTEREST OF THE DISPLACED EQUiTY METHOD}

To value a given project, the displaced equity method just requires to know the schedule of the amounts of outstanding debt associated with this project. Every year, the displaced-equity cash flow is the project's after-tax operating cash flow adjusted in a very simple way. Clearly, when the expected outstanding debt amounts are known, using the displaced equity method is the easiest way to calculate the project's net present value, since it does not require the equity residual cash flows to be explicitly computed. For this reason, this new method may be of practical interest for those who are in charge of project valuation in industry or financial institutions.

As mentioned in the introduction, under certain financing assumptions the financial literature recommends using a cost-of-equity value that varies through time. In theory, the project's value must then be computed according to a rather delicate and complex process. In this case, the equity residual method, and therefore the displaced equity method, yield projects' values that are equal to those obtained with other methods (see for instance Inselbag and Kaufold (1997)), provided that the cost-of-equity rates successively used are correctly estimated. We could have introduced the displaced equity method by considering a cost-of-equity rate varying over the project's lifetime, but doing this would have rendered this method - as well as the equity residual method - non-operational whereas calculating a project's equity value and return on equity is widespread practice. For practitioners, assuming a constant cost of equity and using the displaced equity method should most probably be an easy and pragmatic way of estimating a project's value.

\section{REFERENCES}

Chambers, D.R., Harris, R.S. and Pringle, J.J. (1982) Treatment of financing mix in analyzing investment opportunities. Financial Management, 8, 24-41.

Harris, R.S. and Pringle, J.J. (1985) Risk-adjusted discount rates - extensions from the average-risk case. Journal of financial research, 8, 237-244.

Inselbag, I. and Kaufold, H. (1997) Two DCF approaches for valuing companies under alternative financing strategies (and how to choose between them). Journal of Applied Corporate Finance, 10, 114-122. 
Miles, J. and Ezzell, J.R. (1985) Reformulating tax shield valuation: a note. Journal of finance, XL, 1485-1492.

Ruback, R.S. (2002) Capital cash flows: a simple approach to valuing risky cash flows. Financial Management, 31, 85-103.

Taggart, R.A. (1991) Consistent valuation and cost of capital expressions with corporate and personal taxes. Financial Management, 20, 8-20. 


\section{Déjà parus}

CEG-1. D. PERRUCHET, J.-P. CUEILLE,

Compagnies pétrolières internationales : intégration verticale et niveau de risque.

Novembre 1990

CEG-2. C. BARRET, P. CHOLLET,

Canadian gas exports: modeling a market in disequilibrium.

Juin 1990

CEG-3. J.-P. FAVENNEC, V. PREVOT,

Raffinage et environnement.

Janvier 1991

CEG-4. D. BABUSIAUX,

Note sur le choix des investissements en présence de rationnement du capital.

Janvier 1990

CEG-5. J.-L. KARNIK,

Les résultats financiers des sociétés de raffinage distribution en France 1978-89.

Mars 1991

CEG-6. I. CADORET, P. RENOU,

Élasticités et substitutions énergétiques : difficultés méthodologiques.

Avril 1991

CEG-7. I. CADORET, J.-L. KARNIK,

Modélisation de la demande de gaz naturel dans le secteur domestique : France, Italie, Royaume-Uni 19781989.

Juillet 1991

\section{CEG-8. J.-M. BREUIL,}

Émissions de SO2 dans l'industrie française : une approche technico-économique.

Septembre 1991

CEG-9. A. FAUVEAU, P. CHOLLET, F. LANTZ,

Changements structurels dans un modèle économétrique de demande de carburant.

Octobre 1991

CEG-10. P. RENOU,

Modélisation des substitutions énergétiques dans les pays de l'OCDE.

Décembre 1991

CEG-11. E. DELAFOSSE,

Marchés gaziers du Sud-Est asiatique : évolutions et enseignements.

Juin 1992

CEG-12. F. LANTZ, C. IOANNIDIS,

Analysis of the French gasoline market since the deregulation of prices.

Juillet 1992

CEG-13. K. FAID,

Analysis of the American oil futures market.

Décembre 1992

CEG-14. S. NACHET,

La réglementation internationale pour la prévention et l'indemnisation des pollutions maritimes par les hydrocarbures.

Mars 1993 


\section{CEG-15. J.-L. KARNIK, R. BAKER, D. PERRUCHET,}

Les compagnies pétrolières : 1973-1993, vingt ans après.

Juillet 1993

\section{CEG-16. N. ALBA-SAUNAL,}

Environnement et élasticités de substitution dans l'industrie ; méthodes et interrogations pour l'avenir.

Septembre 1993

\section{CEG-17. E. DELAFOSSE,}

Pays en développement et enjeux gaziers : prendre en compte les contraintes d'accès aux ressources locales. Octobre 1993

\section{CEG-18. J.P. FAVENNEC, D. BABUSIAUX,*}

L'industrie du raffinage dans le Golfe arabe, en Asie et en Europe : comparaison et interdépendance.

Octobre 1993

\section{CEG-19. S. FURLAN,}

L'apport de la théorie économique à la définition d'externalité.

Juin 1994

\section{CEG-20. M. CADREN,}

Analyse économétrique de l'intégration européenne des produits pétroliers : le marché du diesel en Allemagne et en France.

Novembre 1994

\section{CEG-21. J.L. KARNIK, J. MASSERON,*}

L'impact du progrès technique sur l'industrie du pétrole.

Janvier 1995

CEG-22. J.P. FAVENNEC, D. BABUSIAUX,

L'avenir de l'industrie du raffinage.

Janvier 1995

CEG-23. D. BABUSIAUX, S. YAFIL,*

Relations entre taux de rentabilité interne et taux de rendement comptable. Mai 1995

\section{CEG-24. D. BABUSIAUX, J. JAYLET,*}

Calculs de rentabilité et mode de financement des investissements, vers une nouvelle méthode ? Juin 1996

\section{CEG-25. J.P. CUEILLE, J. MASSERON,*}

Coûts de production des énergies fossiles : situation actuelle et perspectives. Juillet 1996

CEG-26. J.P. CUEILLE, E. JOURDAIN,

Réductions des externalités : impacts du progrès technique et de l'amélioration de l'efficacité énergétique. Janvier 1997

\section{CEG-27. J.P. CUEILLE, E. DOS SANTOS,}

Approche évolutionniste de la compétitivité des activités amont de la filière pétrolière dans une perspective de long terme.

Février 1997

CEG-28. C. BAUDOUIN, J.P. FAVENNEC, Marges et perspectives du raffinage. Avril 1997 
CEG-29. P. COUSSY, S. FURLAN, E. JOURDAIN, G. LANDRIEU, J.V. SPADARO, A. RABL,

Tentative d'évaluation monétaire des coûts externes liés à la pollution automobile : difficultés méthodologiques et étude de cas.

Février 1998

CEG-30. J.P. INDJEHAGOPIAN, F. LANTZ, V. SIMON,

Dynamique des prix sur le marché des fiouls domestiques en Europe.

Octobre 1998

CEG-31. A. PIERRU, A. MAURO,

Actions et obligations : des options qui s'ignorent.

Janvier 1999

CEG-32. V. LEPEZ, G. MANDONNET,

Problèmes de robustesse dans l'estimation des réserves ultimes de pétrole conventionnel.

Mars 1999

CEG-33. J. P. FAVENNEC, P. COPINSCHI,

L'amont pétrolier en Afrique de l'Ouest, état des lieux

Octobre 1999

CEG-34. D. BABUSIAUX,

Mondialisation et formes de concurrence sur les grands marchés de matières premières énergétiques : le pétrole.

Novembre 1999

CEG-35. D. RILEY,

The Euro

Février 2000

CEG-36. et 36bis. D. BABUSIAUX, A. PIERRU, ${ }^{*}$

Calculs de rentabilité et mode de financement des projets d'investissements : propositions méthodologiques. Avril 2000 et septembre 2000

CEG-37. P. ALBA, O. RECH,

Peut-on améliorer les prévisions énergétiques ?

Mai 2000

CEG-38. J.P. FAVENNEC, D. BABUSIAUX,

Quel futur pour le prix du brut?

Septembre 2000

ECO-39. S. JUAN, F. LANTZ,

La mise en œuvre des techniques de Bootstrap pour la prévision économétrique : application à l'industrie automobile

Novembre 2000

ECO-40. A. PIERRU, D. BABUSIAUX,

Coût du capital et étude de rentabilité d'investissement: une formulation unique de l'ensemble des méthodes.

Novembre 2000

ECO-41. D. BABUSIAUX,

Les émissions de $\mathrm{CO} 2$ en raffinerie et leur affectation aux différents produits finis

Décembre 2000

ECO-42. D. BABUSIAUX,

Éléments pour l'analyse des évolutions des prix du brut.

Décembre 2000 


\section{ECO-43. P. COPINSCHI,}

Stratégie des acteurs sur la scène pétrolière africaine (golfe de Guinée).

Janvier 2001

\section{ECO-44. V. LEPEZ,}

Modélisation de la distribution de la taille des champs d'un système pétrolier, LogNormale ou Fractale ? Une approche unificatrice.

Janvier 2001

\section{ECO-45. S. BARREAU,}

Innovations et stratégie de croissance externe : Le cas des entreprises parapétrolières.

Juin 2001

ECO-46. J. P. CUEILLE,

Les groupes pétroliers en 2000 : analyse de leur situation financière.*

Septembre 2001

ECO-47. T. CAVATORTA,

La libéralisation du secteur électrique de l'Union européenne et son impact sur la nouvelle organisation électrique française

Décembre 2001

ECO-48. P. ALBA, O. RECH,

Contribution à l'élaboration des scénarios énergétiques.

Décembre 2001

ECO-49. A. PIERRU,*

Extension d'un théorème de dualité en programmation linéaire : Application à la décomposition de coûts marginaux de long terme.

Avril 2002

\section{ECO-50. T. CAVATORTA,}

La seconde phase de libéralisation des marchés du gaz de l'Union européenne : enjeux et risques pour le secteur gazier français.

Novembre 2002

\section{ECO-51. J.P. CUEILLE, L. DE CASTRO PINTO COUTHINO, J. F. DE MIGUEL RODRÍGUEZ,*}

Les principales compagnies pétrolières indépendantes américaines : caractéristiques et résultats récents.

Novembre 2002

\section{ECO-52. J.P. FAVENNEC,}

Géopolitique du pétrole au début du $\mathrm{XXI}^{\mathrm{e}}$ siècle

Janvier 2003

\section{ECO-53. V. RODRIGUEZ-PADILLA,}

avec la collaboration de T. CAVATORTA et J.P. FAVENNEC,*

L'ouverture de l'exploration et de la production de gaz naturel au Mexique, libéralisme ou nationalisme

Janvier 2003

\section{ECO-54. T. CAVATORTA, M. SCHENCKERY,}

Les majors pétroliers vers le multi énergies : mythe ou réalité ?

Juin 2003

\section{ECO-55. P.R. BAUQUIS,*}

Quelles énergies pour les transports au $\mathrm{XXI}^{e}$ siècle?

Janvier 2004 
ECO-56. A. PIERRU, D. BABUSIAUX,

Evaluation de projets d'investissement par une firme multinationale : généralisation du concept de coût moyen pondéré du capital et conséquences sur la valeur de la firme.

Février 2004

ECO-57. N. BRET-ROUZAUT, M. THOM,

Technology Strategy in the Upstream Petroleum Supply Chain.

Mars 2005

ECO-58. A. PIERRU,

Allocating the $\mathrm{CO}_{2}$ emissions of an oil refinery with Aumann-Shapley prices.

June 2005

ECO-59. F. LESCAROUX,

Les conséquences économiques de la hausse du prix du pétrole.*

Mai 2006

ECO-60. F. LESCAROUX, O. RECH

L'origine des disparités de demande de carburant dans l'espace et le temps : l'effet de la saturation de l'équipement en automobiles sur l'élasticité revenu.

Juin 2006

ECO-61. C. I. VASQUEZ JOSSE, A. NEUMANN,

Transatlantic Natural Gas Price and Oil Price Relationships - An Empirical Analysis.

Septembre 2006

ECO-62. E. HACHE,

Une analyse de la stratégie des compagnies pétrolières internationales entre 1999 et 2004.

Juillet 2006

ECO-63 F. BERNARD, A. PRIEUR,

Biofuel market and carbon modeling to evaluate French biofuel policy.

Octobre 2006

ECO-64. E. HACHE,

Que font les compagnies pétrolières internationales de leurs profits?

Janvier 2007

ECO-65. A. PIERRU,

A note on the valuation of subsidized Loans - Working paper

Janvier 2007

ECO-66. D. BABUSIAUX, P. R. BAUQUIS,*

Que penser de la raréfaction des ressources pétrolières et de l'évolution du prix du brut?

Septembre 2007

ECO-67. F. LESCAROUX,

Car ownership in relation to income distribution and consumers's spending decisions.

Novembre 2007

ECO-68. D. BABUSIAUX, A. PIERRU,

Short-run and long-run marginal costs of joint products in linear programming

Juin 2008

ECO-69. E. HACHE,

Commodities Markets: New paradigm or new fashion?

Juillet 2008

* une version anglaise de cet article est disponible sur demande 